\title{
Terrorism: \\ A Reflection on the Dynamics of Contemporary Suicide Terrorism
}

\author{
Mediel HOVE \\ Vincent CHENZI
}

\begin{abstract}
Suicide terrorism has evaded understanding and the war on terror is failing in its attempt to counter and even control it. This article argues that suicide terrorism is largely caused by indoctrination and, therefore, the key to understand and defeat it is through weakening and even conquering indoctrination carried out by terror organizations. It further asserts that although other factors such as finance, weapons, religion, political environment, structured organization, infrastructure and sponsors contribute to suicide operations, they are not central. To this end, efforts to counter suicide terrorism should focus

Mediel HOVE

Research Associate, International on ending radicalisation and/or indoctrination of individuals and communities.
\end{abstract}

Centre for Nonviolence

Durban University of Technology,

Durban, South Africa

and a Senior Lecturer,

History Department,

University of Zimbabwe

E-mail: medielhove@yahoo.co.uk

Vincent CHENZI

Teaching Assistant

University of Zimbabwe,

E-mail: chenziv05@gmail.com

Conflict Studies Quarterly

Issue 20, July 2017, pp. 67-89

DOI:10.24193/csq.20.5

Published First Online: 2017/07/3
Keywords: Suicide terrorism, indoctrination, terrorist, religion, Islamic State, Social media.

Acknowledgments. The researchers communicate their warm, non-stop and thoughtful appreciation to all authors whose works were used during the writing of this article. At last, we convey our sincere thanks to our families for their spiritual, financial and moral support during the writing of this manuscript.

\section{Introduction}

The debates on terrorism have created controversial definitions. The most popular definition refers to terrorism as a deliberate and systematic use of random violence on the "innocent" carried out to create fear 
on a targeted audience in order to realize political ends. This definition is controversial because the so called terrorists in one scenario are sometimes viewed as liberators in another and the so-called victims are also regarded as terrorists depending on the perspective of either the victim or perpetrator (Cronin, 2002; Wolfendale, 2007; Walzer, 1977; Legault, 1992; Levinson \& Christensen, 1996; Kaarbo \& Ray, 2011; Atran, 2003). Suicide terrorism is another branch of terrorism and can be defined as violent and politically motivated self-destructive violence committed by a "terrorist" by blowing himself or herself whilst killing others at the same time through the use of bomb loaded cars, planes or clothing (Bunker and Sullivan, 2004; Bloom, 2005, 113; Atran, 2003; Moghadam, 2005, 2008). The terror and fear generated by the act is the main reason for the suicide attack and is designed to force a targeted group to succumb to the demands of the perpetrators. Suicide terrorism, like ordinary terrorism, also contains controversies because the suicide terrorist is considered a martyr by the supporters of the act whilst the targeted victims of the attack usually refer to the perpetrators as psychopathic self-destructive murderers (Bunker \& Sullivan, 2004; Levinson \& Christensen, 1996).

This article focuses on suicide terrorism because it has been gradually increasing and spreading into new territories since the 1980s with limited signs of reduction. Added to this, the article clarifies several misunderstandings that are held by both experts and the general public in relation to the conduct, operation and responses to suicide terrorist activities. It also examines the extent to which these unfounded beliefs have undermined attempts to curb the spread of suicide terror operations. Prominent among these beliefs are the assertions that suicide terrorists are poor, uneducated, psychologically lacking and that giving in to the demands of suicide bombers will end hostilities. Furthermore, some scholars assert that the killing or detaining of terrorist leaders will lead to an end of suicide operations and the responsible organization and targeting the financial resources of a terrorist organization leads to its destruction. These beliefs explain why attempts to curb suicide terror attacks have always resulted in utter failure. This article advances the thesis that suicide terrorism, unlike any other form of terrorism, has its backbone and foundation in its capability to indoctrinate. Usually, terrorist organisations fuse religious and political indoctrination (Brym, 2007).

All the organisations responsible for suicide terrorism depend on a body, clique or department of propagandists responsible for conditioning and inducing the belief that the organisation's cause is much more valuable than one's life. Indoctrination is the most vital aspect of all suicide terrorist organisations both past and present, therefore, the existence of a suicide terrorist organisation does not necessarily require weaponry, financial or religious backing. It concludes that targeting the terrorist organisations' financial, political, leadership, religious, structural or infrastructural resources, without weakening their capability to indoctrinate, will not completely destroy the terrorist organisations. This explains why the war on terror has failed to curb suicide terrorism 
in the past two decades. More so, non-military counter propaganda measures have recently proven to be successful in permanently crippling terrorist organizations. A case in point is Al-Qa'ida in Iraq, which generated such resentment among its subjects such that it laid the foundations for the Sunni Awakening that ultimately destroyed its hold (Quintana, 2015).

The article is divided into five sections. The first section provides a theoretical framework which is hinged on indoctrination. In the second section, we provide a brief history of suicide cases. Myths, misunderstandings and stereotypes surrounding suicide terrorism are explored in the third section whilst the fourth part examines indoctrination and counter propaganda campaigns applied by terrorist organisations. The recommendations and conclusion comprise the last section.

\section{Theoretical framework}

In this article, we engage the theory of indoctrination propounded by Frank Salter (2008) in his manuscript, Ethnicity and Indoctrination for Violence: The Efficiency of Producing Terrorists. He claims that suicide terrorism would be very low without the systematic education and deliberate removal of restraint and human values in order to create a dedicated suicide bomber. He further notes that indoctrination is merely a necessary condition for suicide terrorism but is highly inefficient as a sufficient cause for routine terrorism (Salter, 2008). Contrary to Salter, we assert that terrorism, in general, and suicide terrorism, in particular, is hinged on and perpetuated through indoctrination, be it religious or circular. This does not mean that all the other factors which contribute to terrorism, such as the organization, environment, finance, resources, among others, are not important. They are peripheral in terms of perpetuating suicide terrorism when compared to indoctrination. Indoctrination is not only carried out on the suicide terrorist, but is also induced on the communities which passively or actively support suicide terrorism.

Indoctrination, according to the Merriam Webster dictionary, is the practice of teaching a particular person in order for that person to totally accept and adopt the opinions, ideas and belief systems of a certain group so as to reject any other beliefs, opinions and ideas from any other group (Merriam-Webster, 2016). In suicide terrorism, the ability and skill required to transform a human being from a self-preserving social animal into a selfless, self-destructive walking bomb requires a high level of convincing, brain washing, conditioning and training that is rare and unique (Iqbal, 2010). Trainers adept at the art of deception, sophistry and propaganda which make the catholic indulgences of the past to appear like child's play are responsible for the indoctrination process. Communities and members of terrorist organisations are indoctrinated by these charismatic teachers who distort and blur the lines of religion, politics and society by instilling their own version of the world into the followers. Some of these former and modern 
teachers of suicide terrorism include Abdullah Azzam, Osama bin Laden's mentor, the late Osama bin Laden, Ayman al-Zawahiri leader of al-Jihad an Egyptian terrorist group, Abu Hamza al-Mazri and Omar Bakri Muhammed, the two great Salafi jihadist preachers, Abu Ayman al-Hilali, and Baitullah Mehsud among many others (Sela-Shayovitz, 2007; Iqbal, 2010; Moghadam, 2008). It is our submission that without the influence of these teachers, thousands would not have volunteered to become suicide bombers and thus without indoctrination the cases of contemporary suicide terrorism would be very low.

Propaganda, distortions and outright lies are delivered to the members in concealed places via a propaganda network of indoctrination (Martin \& Weinberg, 2016) and claims which include but not limited to: assertions that dying through suicide terrorism is a holy and noble gesture which is painless, honourable and bestows martyrdom status and a ticket to paradise (Ganor, 2007). Heavenly rewards through the washing of sins with one's blood opening the doors to paradise where angels will usher the pure soul to await great riches accompanied by 72 virgins who will serve the martyr forever whilst 70 relatives of the volunteer suffering the torments of hell will also be accepted into paradise. More so, the teachers impart that a sit very close to the prophet Mohamed and almighty Allah will also be reserved for the martyr (Marone, 2013; Iqbal, 2010; Moghadam, 2008; Sela-Shayovitz, 2007). These are some of the promises that are indoctrinated into the members. Those who are suffering financial difficulties are given a large sum of money for their relatives whilst they will be broadcast in the local television stations before and after they commit suicide bombing (Iqbal, 2010; Brym 2007).

\section{A reflection on suicide terror attacks}

It is vital to note that terrorism, in general, and suicide operations, in particular, are not recent phenomena but can be traced as far back as three millenniums during the pre-Christian era (Kaarbo \& Ray, 2011). The first ever recorded suicide assault took place around 1078 BCE in the Middle East, during the reign of Samson when he prayed to God after he had been captured by the Philistines to give him strength to destroy the Philistines and himself by collapsing the Philistine temple (Rudd, 2016). However, contemporary suicide terrorism is believed to have emerged in the early 1980s, during the Lebanese civil war. The first recorded modern suicide terrorist act was a suicide car bombing on the Iraqi embassy in Beirut which killed 61 people, including the former Ambassador Abdul Razzak Lafta, on 15 December 1981 (Bunker \& Sullivan, 2004; Atran, 2003; Moghadam, 2005). Since then, about 1,857 suicide bombings were recorded between December 1981 and March 2008 and the suicide attacks increased year after year. Until the mid-1990s, suicide attacks did not exceed seven bombings each year. There was a rapid increase of suicide terrorism after the $9 / 11$ attack in 2001. Accordingly, in 2001, there were 54 attacks followed by 71 in 2002, whilst 2003 had 81, which were lower than 104 in 2004, 2005 had 348, with 2006 having 353, which are far less compared to 535 attacks of 2007 (Lankford, 2011; Moghadam, 2005; 2008). More so, in 
Nigeria and Somalia, Boko Haram and al-Shabaab have recently linked with al-Qaeda and intensified and expanded their operations in North Africa (Barton, 2016). In the Middle East, the 2003 US invasion of Iraq and the recent Syrian civil war led to the hegemony of al-Qaeda's spin-offs which assumed political power. This is true of the Islamic State (IS or ISIS) which was formed in June 2014 with a major objective of creating the former Islamic global caliphate which stretched from Morocco to Spain in the West and as far as India in the East (Quintana, 2015). In 2016, ISIS was controlling one third of north western Iraq and half of northern Syria (Hughes, 2016; Schmid, 2015; Barton, 2016) although it is "neither Islamic nor a state" because it attacks civilians, including women and children (Cusack, 2016). Moreover, it destroys property, murders other Muslims who hold different opinions and this is forbidden in the Islamic law (Daftary, 2016). ISIS attracted at least 20,000 foreign fighters from at least 100 states and these are operating inside Syria and Iraq (Schmid, 2015). It has been estimated that there was a 70\% increase in foreign fighters who joined terrorist groups between mid-2014 to March 2015. As a result of this rapid growth in the cases of suicide terrorism, it is imperative to find out why they are continuously and gradually escalating despite the September 2014 counter-terrorism coalition created by the then US president, Barak Obama, comprising of sixty-three states (Quintana, 2015).

Since the beginning of 2015, the Middle East, Africa and Asia have seen nearly 50 times more deaths from terrorism than Europe and the Americas. The Middle East and Northern Africa account for over two-thirds of terrorism deaths since January 2015, with multiple attacks occurring daily, each claiming on average at least a dozen lives. More so, suicide attacks in 2015 were 4.6 times as lethal as compared to non-suicide attacks (Cordesman, 2016). Between January and September 2016, ISIS carried out deadly suicide terror attacks across the globe, including Syria, Belgium, France, Turkey, Egypt, Libya, Saudi Arabia, Indonesia, Nigeria, Iraq and Yemen, among others, which left over a thousand fatalities, tens of thousands injured and psychologically affected although it had experienced terrible territorial loses and close to a third of its fighting force (Tomkiw, 2016).

Suicide terrorist incidences have recently increased and the largest increase for 2015 was in Africa which recorded 122 suicide attacks in 2015, as compared with 32 terror attacks in 2014. The responsible party is Wilayat Gharb Ifriqiyya, the Islamic State's West African group, formerly known as Boko Haram and Ansaru, which joined IS last March. In 2015, 96 suicide attacks took place in Nigeria, 13 in Cameroon, eight in Chad and five in Niger (Issacharoff, 2016). However, the 2015 total global suicide terror attacks were fewer than those in 2014, that is 207 terror attacks in the Middle East in 2015 as opposed to 370 in 2014, which is a 44 percent decline. However, the death count was close to the one recorded in 2014, that is 4,370 people killed in 2015 as compared with 4,400 people killed in 2014 (Issacharoff, 2016; Cordesman, 2016). 
Suicide terrorism does not only take place on the ground but a number of in-flight suicide attacks were experienced inside civilian passenger planes and at airports. Classic examples include Air India Flight 182 on the 23 June 1985, which killed 329 and Sikh extremists were suspected of planting a bomb in the plane (Bronskill, 2015). In the case of the December $21^{\text {st }}, 1988$ Pan Am flight 103 disaster, also called the Lockerbie bombing, Abdelbaset Ali Mohmed al-Megrahi, a Libyan intelligence agent, was suspected of smuggling a suitcase bomb which exploded, killing all 259 passengers and crewmembers, along with 11 people on the ground in Lockerbie, Scotland (Greenspan, 2013). The UTA Flight 772, on 19 September 1989, exploded over the Sahara Desert in Southern Niger, killing all 170 passengers on board (Reynolds, 2003). The 9/11 attacks are at the pinnacle of aviation suicide terrorism and they demonstrated that not even the United States was safe from suicide terror attacks. Since 1931 to 2016, at least 586 civil aviation attacks by terrorist organizations have been recorded (Duchesneau, 2015) and recently, aviation suicide attacks have been on the rise. A case in point is the October $31^{\text {st }}, 2015$ Russian A321 Airbus attack by ISIS en route to Saint Petersburg, killing all the 224 people on board. On 3 February 2016, a bomb planted by Al-Shabaab Al-Mujahideen at Daallo Airlines, a Somali passenger plane, exploded after take-off, blowing a hole on the plane (Azani, Lvovsky, \& Haberfeld, 2016). More so, on 22 March 2016, two Islamic State terrorists blew themselves up at the entrance to the Brussels international airport. On 28 June 2016, during a terror attack at Ataturk International Airport in Istanbul-Turkey, three terrorists opened fire and later detonated themselves with explosive vests, killing at least 40 and injuring over 150 civilians (Azani et al., 2016). Terrorist organisations also made use of drones against the aviation industry and the first case of a crash between a drone and a civil aircraft was reported in London, in April 2016, when a drone hit a British Airways passenger plane as it was landing at Heathrow Airport (Azani et al., 2016).

\section{Myths and stereotypes of suicide terrorism}

In this section, we explore contemporary counter-terrorism attempts and beliefs which are usually grounded in error and how they have perpetuated suicide terrorism despite the availability and application of counter-terrorism measures. However, these suggestions are open to debate and modification. They are put forward to promote a more open minded approach towards countering suicide terrorism. The first assumption that needs to be addressed in counter-terrorism operations is the belief that force or military containment in the form of torture, massacre, detention, air strikes and killing of supporters, leaders, communities and relatives of suspected suicide bombers is a necessary measure towards countering terrorism (Quintana, 2015; Brym, 2007). The use of force in countering suicide terrorism is largely unnecessary and counterproductive and assists in popularising suicide operations as retaliatory attacks (Hove \& Ndawana, 2017; Kaplan, Mintz, \& Mishal, 2006; Quintana, 2015; Bronk, 2015). These 
violent repressive actions, if at all successful, are usually short-lived. They generally lead to the support of religious and community organizations and even create potential recruits and the desire to revenge due to the inflicted violence which gives more credibility to organizations that use suicide terrorism (Kaplan et al., 2006; Brym, 2008; Iqbal, 2010). A case in point was the Israeli counter-terror which was surveyed in 2002 via a poll of 1179 Palestinians from the West Bank and Gaza of which 66\% claimed that the military operations increased their support for suicide operations whilst $73 \%$ of the Lebanese Moslems viewed suicide as a justifiable form of martyrdom (Kimhi \& Even, 2004; Brym, 2007; Atran, 2003). During the second intifada, Hamas claims to have altered its strategy by approving and encouraging suicide terrorism and rocket attacks on civilians in response to repression, coercion and extreme violence from the Israeli forces (Araj \& Brym, 2010). More so, from August 2014 to August 2015, more than 10,600 separate Islamic State targets had been hit and 10,000-15,000 ISIS fighters killed by US air strikes alone but these tactical victories made little strategic impact on the overall military capacity of ISIS as it continues to recruit more forces from its sympathizers (Bronk, 2015).

However, there are instances where harsh state repression has not given rise to suicide terrorism or any form of terrorism (Brym, 2008). We believe that the reason for this phenomenon is the absence of indoctrination on the oppressed groups which can encourage them to adopt extreme retaliatory measures, including suicide terrorism against their oppressors. More so, other experts believe that brutal force and violent retaliatory measures against suicide terrorists and their communities is an effective counter-measure and this is also the same opinion held by most governments facing the threat of suicide terrorism (Ní Aoláin, 2016) but the major question which arises is "If this method really works, why is suicide terrorism increasing geographically and numerically with each passing year despite the brutality and violence meted against it?". A case in point is ISIS which has lost ground in Iraq and Syria and has been pushed back from North-East Syria, Shingal, Hasakah province, Raqqa and Sirte. More so, it has lost a third of its manpower from 30,000 in 2014 down to 22,000 in 2016 (Iddon, 2016). Despite these territorial and manpower setbacks, ISIS has recently increased suicide attacks on Western targets (Iddon, 2016).

There is also the belief that targeting the leaders of suicide terrorist organizations to remove the brains and initiative of the organization can effectively thwart and end the very organization itself. However, this assumption is also very controversial because the killing of Osama bin Laden by the United States forces, as a reaction after the 9/11 attacks, did not mean the end of Al Qaeda. Rather, Al Qaeda expanded into a global terrorist organization and has hatched many spin-offs and affiliate organizations such as the Taliban in Afghanistan, ISIS in Iraq and Syria, Djabhat an-Nusrah in Syria, Boko Haram in Nigeria, Lashkar-e-Jangvi in Pakistan, Tehrik-e-Taleban in Pakistan, al-Shabab 
in Somalia, despite the killing of most of its leaders (Global Terrorism Index, 2014). Although al-Qaeda has been silent in the past five years, the presence of these affiliate organizations has compelled many experts to view them as al-Qaeda in the Islamic Maghreb, al-Qaeda in the Arabian Peninsula, al-Qaeda in Iraq, al-Qaeda in South-East Asia and al-Qaeda in the North and Horn of Africa (Global Terrorism Index, 2014). This indicates that radical Islamic terrorist organisations are not built around their founders and leaders but on their doctrines, which means that the death of the leader is simply a martyr's death raising more leaders and organizations to take their place like the mythical ten headed hydra (Brown, 2016).

However, there are instances where violence and heavy-handed tactics can be used, especially when fighting an unpopular organisation that neglects indoctrinating its community so as to gain social acceptance and support for embarking on suicide operations. A case in point is Boko Haram which resorted to kidnapping young children below ten years which is said to have increased 11 times after a combined military force removed them from most parts of Nigeria. These young children were and still are forced to carryout suicide operations by being strapped with explosives on crowded areas. As a result, Boko Haram lost its legitimacy and support from the communities it operates (Searcey, 2016). This form of nefarious child suicide terrorism is being applied by Boko Haram in Nigeria, Cameroon and Chad and cannot be thwarted by counter-ideological means but by outright force and violence. This is because children do not need ideological propaganda to convince them to become suicide terrorists. They can easily be intimidated into carrying lethal weapons without their knowledge which raises the question whether this is suicide terrorism or outright murder of the innocent and operations which does not include the mutual acceptance of the bomber are not categorised as suicide terrorism or suicide (Lankford, 2011).

It is imperative to also examine the belief that contemporary suicide terrorism is a byproduct of religious groups (Sela-Shayovitz, 2007), since this is what the suicide terrorist organizations want the world to believe. These radical Islamic terrorist organisations are seeking to address political, economic and social grievances in order to establish political and economic power via religious means and this does not make them religious, but rather opportunistic, since radical Islam condones violent means in wagging a Jihad (holy war). Available evidence indicates that not all suicide terrorist activities have been carried out by religious groups since some suicide attacks have also been carried out by secular terrorist organizations. Around 60\% of the world's suicide attacks from 1983 to 2000 were conducted by the Sri Lankan Tamil Tigers who are basically a political organization which is non-religious and non-Muslim (Brym, 2012; Bloom, 2005). More so, from 1980 to 2003, suicide attacks which have a visible cultural and ideological background reveal that only $43 \%$ of the cases had a semblance of religious involvement (Brym, 2012; Araj, 2008). To this end, one can conclude that the majority of radical 
religious suicide terrorist organisations are inherently politically driven and most of their grievances are political and economic rather than religious, although religion is used to ensnare and attract members of the same religious community to rally behind these terrorist organisations. Religion is also used to inspire the feelings of martyrdom from the supporters of the cause especially where political means to address grievances have failed (Bloom, 2005; Marone, 2013; Brym, 2007). This means that suicide terrorist organisations give a religious outlook to their operations in order to indoctrinate their targeted sympathisers. This is done so as to wage a conflict which transcends political and circular bindings giving a picture that the survival of their religion and very existence is at stake. Therefore, all tactics, including suicide operations, are permissible in the struggle to survive real and imagined threats. These extremes are highly unlikely to achieve the objectives devoid of the circular means which deal with a conflict that crosses the boundary of religion against a common enemy.

There also exists the belief that destroying all financial support (terror financing) from a suicide terrorist organisation will culminate in its destruction (Quintana, 2015; Troy, 2006; Lankford, 2011). Conversely, practical evidence has proven that some terrorist organisations had lost their financial resources and capacity but continued to wage suicide operations. Hamas, for example, when it started utilizing suicide bombing in 1993, lacked military weapons of any kind but survived through the ingenious attempts of Yahya Ayash, the famous bomb maker who used soap, sugar and other house hold products to make bombs, which he in turn taught others to do the same (Araj \& Brym, 2010). More so, soon after the $9 / 11$ attacks, the US launched a global war against terror by blocking Al Qaeda's known and possible terror financing systems but terror activities continue and the terrorists still boast about their financial capabilities (Troy, 2006). It is critical to also realize that some terrorist organisations have interests and investments in oil, opium and financial institutions in Western countries. This has hindered counter-terror financing endeavors. As a case in point, al-Qaeda was rumored to have investments in the Anglo-American cooperation and this undermined the efforts of the US's war on terror since attacking al-Qaeda's investments was tantamount to selfinflicted damage (Marshal, 2010).

Another contested belief declares that terrorists are poverty stricken, illiterate and psychologically unstable (Brym \& Araj, 2012; Iqbal, 2010). These beliefs are based on the fact that recruits for suicide operations take part because they are promised material rewards for their "poor" families and that they are easily swayed into committing the suicide bombings due to their low educational levels and mental instability (Iqbal, 2010). Nevertheless, at least $47 \%$ of suicide terrorists have university education and an additional $29 \%$ have at least a high school education (RUSI, 2007). More so, there is the danger that hiring a mentally unstable person can jeopardies the organisation's operation and plans, thus, this is avoided at all costs. 
It is widely accepted that granting some of the demands of terrorist organisations will lessen or even end extreme hostilities, such as suicide operations, by empathizing the feelings and grievances of the suicide terrorists and their communities (Brym, 2007). Such measures have encouraged, rather than lessen, future hostilities, especially where circumstances prove to be unfavourable to terrorist organisations, they simply resort to suicide terror as a trump card to turn the situation in their favour (Brym \& Araj, 2008). Furthermore, the reason why suicide terrorism is currently a popular strategy is partly because it usually yields results because nations have been known to give in to the demands of terrorist organisations which apply suicide operations. A case in point is where the suicide operations greatly contributed to the American and French withdrawal from Lebanon in the 1980s (RUSI, 2007). Ever since, a greater majority of known terrorist organizations have resorted to suicide operations due to its effective impact (Bloom, 2005; Araj, 2008; Atran, 2003; Kimhi \& Even, 2004; Marone, 2016; Brym $\&$ Hamlin, 2009). In addition, suicide terrorist operations are very cheap to conduct because there is no fear of capture or planning exit strategies, has minimum supervision, is precise, unpredictable, creates widespread panic and attracts a lot of attention (Bunker \& Sullivan, 2004; Sela-Shayovitz, 2007; Moghadam, 2008; Atran, 2003).

\section{Indoctrination and Counter-propaganda}

Despite the superiority in weapons, soldiers, funding, logistics, technology and resources enjoyed by the organisations and countries seeking to annihilate the threat of suicide terrorism, such as the United Nations, United States and allies have weak propaganda and indoctrination systems compared to those used by suicide terrorist organizations (Lawson, 2015). Concerning terrorist superior indoctrination tactics, Lawson (2015) stated in relation to the failure of the coalition against ISIS that:

It is widely perceived in the West that the group has been running a successful public- relations campaign that has significantly contributed to recruitment, particularly of foreign fighters, as well as success on the battlefield. In contrast, it is less clear that coalition efforts have had the same coherence and effectiveness either strategically or tactically (p. 29).

Added to this, indoctrination plays critical roles in recruiting, training, seeking funding, creating suicide terrorists, conditioning recruits and members, uniting and directing the terrorist organisation. Therefore, indoctrination is a key feature of suicide terrorism and attempts to analyse or counter it without a deeper scrutiny of its role are bound to fail. Furthermore, terrorist organizations that utilise suicide terrorism as part of their strategy mainly depend on indoctrinating their members and communities to sympathize and participate. This helps them to be able to recruit and prepare members for suicide operations. Thus, suicide terrorism unlike any other form of terrorism is hinged on the organization's ability to convince its followers to sacrifice their lives for the common 
cause which is a very complicated task which requires time, patience and cunningness so as to convince a stranger to forfeit their life for the common good (Iqbal, 2010). It is highly likely that this indoctrination is carried out at several levels such as personal, communal, national and, at times, international and the more powerful the indoctrination, the more powerful the organization becomes. We thus believe that coming up with a counter-narrative which is contrary to the terrorist narrative or indoctrination agenda should take centre stage as we believe that a terrorist organization without a strong narrative or the ability to perpetuate its narrative will eventually die a natural death. Thus, the battle of the narratives should be won first before the real battle should be waged against terrorist organizations for a certain victory to be realized.

Indoctrination is a unique feature of suicide terrorism because no other organization, whether military or civilian, applies the levels of indoctrination to the extent of suicide terrorist organizations (Grimland, Apter, \& Kerkhof, 2006). More so, indoctrination bridges the gap where suicide terrorism lacks in training, education, logistics and weaponry. This does not imply that all suicide terrorists are brainwashed because some volunteer for personal reasons without the need for indoctrination. The credit and interpretation of their suicide operation remains the preserve of a particular suicide terrorist organization. This implies that indoctrination is not only practiced on the members but on both victims and the wider community because it is usually used in the aftermath of an attack by a terrorist organisation to broadcast their views by twisting the reasons for the attack as if the victim volunteered for the sake of the cause of the organization (Grimland et al., 2006).

A surplus of promises, rewards and benefits constitute part and parcel of the indoctrination agenda. Poor and suffering members who "volunteer" to be "martyrs" are often given monetary rewards as much as $£ 17,000$ (US\$25,000) (RUSI, 2007), whilst those who are deeply religious are given promises and assurances of eternal glory, paradise, 72 virgins in the afterlife, posthumous glory, sainthood and a close seat beside their God (Iqbal, 2010; Atran, 2003; Sela-Shayovitz, 2007; Marone, 2016; Brym, 2007; Moghadam, 2005). Hence, suicide operations would be rare and very limited if indoctrination did not continue to recruit, guide and perpetuate suicide operations. There are circumstances whereby suicide bombers voluntarily choose to undergo suicide operations partly as a result of the desire to revenge, whilst others have personal problems such as the desire to restore family honour, remove foreign presence and others simply have suicidal tendencies (Iqbal, 2010; Brym, 2007; Atran, 2003; Marone, 2016; Sela-Shayovitz, 2007; Bunker \& Sullivan, 2004). Nevertheless, these different reasons are cunningly twisted such that the victims appear to have committed the act for a common grievance since the explanation and credit for the act is interpreted by the organisation as part of the indoctrination process.

Indoctrination is used in a moral dimension, especially the belief that the targeted enemy is morally inferior in character, religion and code of the suicide terrorist and 
is thus justified in attacking and eliminating them. This explains why suicide terrorist organizations adopt radical Islam, not because they are religious people, but because of its uncompromising nature towards morality and its strict code of conduct which is used in justifying the elimination of 'unbelievers'. This strict moral code is directly in contrast with the Western lifestyle where women wear what they want and have equal rights with men, whilst the Lesbians, Gays, Bisexuals and Transsexuals (LGBT) are constitutionally recognized and promiscuity is normal. All these are taboos gravely forbidden by adherents of radical Islam who believe that crusades against such morally inferior humans are justifiable and encouraged in an attempt to restore order and stability. This explains the recent attacks on gay clubs by Islamic State affiliates (Ellis, Fantz, Karimi, \& McLaughlin, 2016).

Communities that condone and support suicide terrorism have undergone heavy indoctrination such that they find nothing wrong with this inhuman form of terrorism. Suicide terrorism in these areas is not due to the terrible human rights violations, foreign presence, political vacuums or any other concocted reasons proffered by organizations operating within these territories (Quintana, 2015). This is so because their grievances are not unique to those territories, the same grievances exist at a much intense level in Africa, for example. Although there are several terrorist organizations in Africa, they did not commit suicide operations "until recently" despite the fact that Africans have suffered more grievous situations which would justify undertaking suicide operations. This is the case largely because Africa lacks a body of propagandists to indoctrinate and condition the masses to accept and even take pride in suicide terrorism. As a result, suicide terrorism is a by-product of intense indoctrination and where there is no indoctrination there is no suicide terrorism to talk about but there is only suicide. This is also demonstrated in Islamic communities where conventional suicide is highly forbidden and is considered a short-cut to hell whilst suicide terrorism is socially condoned and at times celebrated. This explains why conventional suicide rates are below average whilst suicide terrorist acts are high due to social attitudes towards approval and disapproval of the acts (Lankford, 2011).

Indoctrination is made very easy by the electronic social media outlets such as Twitter, Facebook, Instagram, WhatsApp, YouTube, billboards, posters and radio broadcasts, among others, which have been nicknamed by terrorist organizations as "electronic jihad" (Lawson, 2015). These have also been extensively used by the Islamic State currently operating in Iraq and Syria (Quintana, 2015). There are currently between 50,000 to 70,000 twitter accounts which support ISIS and each of these accounts has an average of 1,000 followers. The twitter accounts are highly active and they tweet intensively mainly focusing on propaganda, recruiting members, psychological warfare, bomb making techniques and weapons tutorials. Furthermore, around 90,000 tweets and other social media communications are broadcast daily in close to 24 languages 
which explains why the Islamic State has managed to recruit and attract sympathizers in more than 100 countries (Schmid, 2015). These electronic media platforms are utilized in the form of video, audio, photographs and written messages. Lawson (2015) summarized ISIS's adroit use of 'electronic jihad' as:

... the group has brought a new level of professionalism to its output using modern production tools and combat-camera footage from GoPro cameras, as well as embracing the use of social media. It has also combined the centralised production of high-quality products with a willingness to see these dispersed by a network of sympathisers with little or no apparent formal direction. Efforts to control the circulation of material by shutting down social-media accounts have been akin to a game of 'whack-a-mole' (p. 30).

More so, ISIS, in order to horn its propaganda and indoctrination campaign, uses a central media command 'Al-Hayat Media Center' which manages seven media branches in video, text, photo, radio and translation which collects information from 38 offices in Egypt, Iraq, Syria, Libya, Caucasus, Algeria, Yemen, Tunisia, Saudi Arabia, West Africa and Afghanistan (Schmid, 2015; Lawson, 2015).

In the United States alone, in 2014, 71\% of the adult population used Facebook whilst $26 \%$ used Instagram and 23\% used Twitter. Worldwide, one in every four people uses a social network, which is a total of 1.47 billion and by 2017 social network users will increase to 2.55 billion, making social media platforms the dominant form of communication worldwide (Wu, 2015). Some of these social networks provide instant and very cheap worldwide communication, for example a tweet on twitter can be instantly read and seen by millions of users from all parts of the globe whilst a public Facebook page is available for every Facebook user to see.

The power of social media can be understood due to the fact that social media users spent 88 billion minutes in July 2011 and by July 2012 the number of minutes had increased by $37 \%$ to 121 billion minutes within one year. More so, an eMaketer research institution observed that in the United States alone, average social network users spend 23 hours per week on the social media platforms either texting, emailing, sharing and other forms of online communication (Gabriel, 2014). The three major online social media platforms which terrorist organizations frequently use are Facebook, Twitter and YouTube. Facebook is currently the largest social media platform with at least 1.31 billion users in January 2014 and 54\% of these users log in regularly whilst the remaining $46 \% \log$ on to Facebook at any given date. The average age of the majority of Facebook users are aged around 30 years. Facebook has also reached a $67 \%$ penetration in the Middle East starting in 2010 and it has provided an easy way for terrorists to share tactical and operational information including, but not limited, to weapon maintenance, bomb recipes and shooting, to name but a few. Facebook has also become a gateway for terrorist organizations to provide links on Facebook web pages to other 
sinister hardcore terrorist websites and it has been used as a platform for hateful terrorist propaganda and extreme ideological messages (Gabriel, 2014). Twitter, unlike Facebook, has been used by terrorist groups for momentary reasons, especially when conducting operations in real time since it is fully accessible on both computers and mobile devices. In mid 2013, Twitter users numbered up to 554,750 000 who tweeted at least 9,100 messages every second which amounts to 58 million messages daily. The majority of Twitter users are aged between 18 to 34 years (Gabriel, 2014). YouTube has more than a billion users who watch around 6 billion hours of videos each month whilst every minute results in hundreds of hours of videos being uploaded. In 2011, YouTube had reached 1 trillion watched videos. More so, it has localized cites in 61 states and in 61 languages. Younis Tsouli, a Morrocan convicted terrorist stated that, "A lot of the funding that the brothers are getting is coming because of the videos. Imagine how many have gone after seeing the videos. Imagine how many have become shahid [martyrs]" (Gabriel, 2014, 10-11). Moreover, Lawson (2015) claims that social-media has been used by ISIS by acting as a gateway to what he describes as the 'grooming' of potential volunteers, perhaps best evidenced by the recruitment of teenage girls as 'Jihadi brides'. ISIS also went a step further in their attempts to attract Western sympathizers by establishing an English-language news magazine, 'Dabiq', which uses enticing imagery and language to appeal to the Western youth (Lawson, 2015; Azani et al., 2016). In addition, the Islamic State has further appealed directly to Western youth through what has been described as 'Jihadi-cool' imagery, even comparing its operations with video games such as Call of Duty (Lawson, 2015). Thus, social media has provided terrorist organizations with a new frontier for indoctrinating the masses without being hindered by nationality and geographical boundaries.

Suicide terrorism is not only based on religious foundations since it can be politically oriented, like is the case among the Tamil Tigers (Bunker \& Sullivan, 2004; Atran, 2003; Marone, 2016). It appears that religion is the easiest way to condition and indoctrinate wide populations as long as they are followers of the same faith. It is widely known that the Koran itself does not condone or encourage followers to commit suicide which means that there is a hidden hand responsible for condoning suicide under the name of a religion which forbids such actions (Sela-Shayovitz, 2007). Indoctrination is also applied on the perpetrators of suicide terrorism by making them believe that they are martyrs and heroes rather than self-destructive cold blooded murderers. The Greek word martyr or witness was first widely used during the early Christian era. It was used in reference to the Christian Apostles, signifying their personal witness to the public life and teachings of Christ which was a risky and life threatening business. Many of these witnesses suffered, rather than inflicted harm on others, which is an opposite feature when considering contemporary suicide terrorists who claim to be martyrs whilst inflicting grievous and indiscriminate harm on others including those whom they claim to fight for (Salter, 2008). Hence, without the white-washing purpose of 
indoctrination, suicide terrorism or in this case 'martyrdom' would be highly improbable to pull followers and would be widely stigmatized even in the regions where it is currently being celebrated and condoned.

\section{Conclusion and Recommendations}

The agenda of countering terrorism has dismally failed partly because of the grounded misconceptions that form the basis for the philosophical foundations which underpin the Western world's understanding of terrorism in general and suicide terrorism in particular. Suicide terrorism is not a war to be fought and won but is ideologically founded and is closely related to the cold war that took place between 1945 and 1991 (Davis \& Jenkins, 2002; Cronin, 2002). As a result, the war on terror will never be won through guns and weapons as long as there are secret organizations that exploit and misinterpret common grievances to justify terror and chaos. The Western nations fail to understand that terrorist organizations are influenced by ideologies which may be religious or political depending on the orientation of their communities and they take advantage of these existing ideologies to justify their actions. Hence, the best way to gain an upper hand in the war on terror is to devise counter-ideologies.

There are several counter-terrorism strategies that can be applied which do not include the use of the military or violence. Suicide terrorism is perpetuated by the media attention that the activities generate rather than the terrorist acts themselves. Thus, there is need to deprive terrorist organizations any media attention which is very vital to any terrorist organization's outlook, but this is a tall task to achieve. Any terrorist act committed by a terrorist organization is made significant due to the media attention that is focused on the act that is, the greater the media attention, the more effective the act becomes. Usually, the victims unknowingly assist in advertising and promoting suicide terrorism whenever they broadcast the acts on public media since this spreads panic, demonstrates the helplessness of the victims whilst at the same time boosting the morale of the perpetrators at the same time proving the effectiveness of terrorist activities and focuses attention on terrorist organizations that would be craving for attention (Moghadam, 2005). This may appear insensitive to the victims but there is need to deny the "oxygen of publicity" to terrorist attacks which would pre-empt, discourage and undermine suicide terrorism and the responsible organization. Added to this, there is need to assure any future volunteers of suicide terror that they will be denied any posthumous glory of any kind instead they must be assured that their sacrifice will be forgotten and interpreted as acts of violence and murder. Every year, an estimated 1,000-7,000 victims are killed from terrorist activities which translates to around 42 people daily, whilst hunger kills 40,000 daily; on the other hand, 500,000 lives are yearly taken by light weapons. Influenza kills 3.9 million each year, whilst HIV/AIDS claims annually 2.9 million lives; 2.1 million lives are extinguished yearly by diarrhea, whilst tuberculosis kills 1.7 million each year (Doward, 2015; Wolfendale, 
2007). These comparisons then indicate that terrorism is given undue attention which is detrimental to the supposed victims of terrorist attacks whilst the "real" deadly killers are ignored by the media.

Indoctrination can also be used against the terrorist organizations that sponsor and promote it, especially by broadcasting on public television the collateral victims of suicide attacks. This is very effective because most suicide operations usually end up killing members of society affiliated or sympathetic to the terrorist cause and it is the killing of these collateral victims that needs to be constantly broadcast in their local communities and languages in order to turn the communities against the terrorist organizations. This will also discourage the use of future suicide attacks and remove the illusion of martyrdom from volunteers since they would feel that they are killing the individuals that they are supposed to defend and sacrifice for, such that their sacrifice will appear to have been in vain.

The closure of terrorist affiliated social network accounts on Facebook, Twitter, Yahoo, Google, Instagram, YouTube, among others, will deal a heavy blow on terrorist organizations since they rely on these social networks for indoctrination, recruiting, funding, communication and spreading of hate speeches to poison the minds of their followers. Moreover, these social networks mentioned above need to promote the idea of opening new accounts which campaign against terrorism, in general, and suicide terrorism, in particular. This will also shrink in size the influence of some of these global terrorist organizations which have members across the globe who use the social network platforms to communicate with their mother organizations. Again, the tracking down of individuals who frequent these terrorists affiliated social network accounts will also go a long way in tracking down and apprehending members of the suicide terrorist organizations.

Isolating or preventing easy access to targets is also a temporary way of reducing immediate suicide attacks. These temporary security measures can thwart suicide bombings from taking place (Iqbal, 2010). A classic example is in Israel where a fence was built around the cities to prevent suicide terrorists from accessing their targets. Between 2001 and 2003 there occurred 83 suicide bombings within the Israeli soil, but after portions of the fence had been completed there were just 16 suicide attacks between 2003 and 2006 and after the fence was completed in 2006, there were only 3 suicide attacks from 2006 to 2009 (Lankford, 2011). However, this is a costly exercise which cannot be applied against global suicide bombings. Despite the fact that preventing suicide bombers from gaining access to their targets greatly reduces the number of suicide attacks, it has to be understood that this is merely a cosmetic solution since it does not remove the resentment and desperate desire to do harm by the suicide bombers and in most cases it greatly increases the existing hostilities.

Widespread media campaigns against suicide terrorism especially in territories prone to suicide attacks will prevent more people from becoming suicide bombers and this 
deprives terrorist organizations from recruiting followers (Atran, 2003). Suicide terrorism is a war that can never be won on the battlefield but on the ideological plane and by ruining and even weakening the ability of the ideologies of terrorist organizations from appealing to the general populace and this will be a sure way to victory (Cronin, 2002). This campaign can be carried out by addressing common grievances through aid and compassion. Moreover, public awareness campaigns, joined by religious authorities through teaching against suicide terrorism and distributing free copies of the Koran in local dialects, which is usually twisted and misinterpreted so as to appear as if it condones suicide terrorism and other inhuman acts, may be an effective strategy. It is imperative to redefine and celebrate real heroes and martyrs and to distinguish them in character and deed from the perverted version of suicide bombers who are named as heroes and martyrs rather than naming them for what they really are (Lankford, 2011; Cronin, 2002; Iqbal, 2010).

Furthermore, terrorist organizations are far ahead in terms of communications, media and publicity campaigns which they used in weaving their suicidal narrative as they utilize various electronic social networks, websites and traditional links to pass on information, recruit and advertise themselves than the US Strategic Command (STRATCOM) which seeks to co-ordinate efforts within the counter terrorist coalition against the Islamic State, to deliver both a counter-narrative to ISIS's and to support the building of the coalition itself (Quintana, 2015; Lawson, 2015). Hence, adding various electronic and print media outlets in suicide terrorism prone territories can help in waging anti-terrorism campaigns. A case in point was in Pakistan where one state controlled television was buttressed by 60 more private television networks which challenged the use of suicide terrorism between 2007 and 2008 and by 2009 support for suicide terrorism had dropped to 5\% from 13\% in 2002 (Iqbal, 2010). These media outlets need to be used especially in announcing the real reasons for suicide attacks since the real motives usually die with the perpetrator and the fact that the ordinary suicide rate is very low in Islamic states due to their religious intolerance. Thus, the majority of potential suicidal individuals choose to volunteer to be suicide bombers for personal reasons such as an incurable disease, barrenness, unwanted pregnancies, scandalous adulteries, homosexuality, collaboration with the enemy, substance abuse and addiction (Lankford, 2011; Moghadam, 2010). This is because the main reason behind suicide terrorism is not the random destruction of property and lives but to capture the world's attention in order to create a platform to air out their own organizational agendas by 'misinterpreting' the real cause of death of the volunteer as an act of self-sacrifice and heroism since the volunteer will not be able to do so. Hence, taking away this ability to interpret the cause of suicide operations will nullify the ability to broadcast and manipulate the society. In addition, the announcement that so and so committed suicide bombing because he or she had contracted a venereal disease or was a homosexual or had an unwanted pregnancy out of wedlock weakens the impact and magnitude of the 
suicide act and will question whether the volunteer really went to paradise because of his or her many sins. Therefore, rather than the act being celebrated as a victory, it will be seen as a cause for shame, hypocrisy and cowardice.

Available data on profiles of suicide terrorists can be effectively utilized to identify, thwart and capture them. Several characteristics have been known to be prevalent on potential suicide bombers, such as individuals among crowds who are extremely nervous and concentrated in appearance, or those with shaven heads and beards which is a ceremonial preparation for the potential suicide bomber for paradise. Other potential suicide bombers wear excessive or baggy clothing to conceal explosives which is very queer in arid regions were suicide terrorism is prevalent. Some suicide bombers wear satchels with a firing switch and wire protruding at the top, whilst others pretend to be pregnant. The Tamil Tigers have been known to wear a necklace with a cyanide capsule which can be consumed in the event of capture to avoid torture and interrogation (RUSI, 2007). Therefore, these common characteristics can be used to quickly screen and identify suicide bombers before a catastrophe takes place by simply interrogating and searching individuals with these characteristics.

Additionally, other profile data reveal that the majority of suicide bombers are male and $83 \%$ of these males are single, $64 \%$ are between 18 to 23 years old, almost all of them are below 30 years and devoutly religious with an Islamic fundamentalist background (RUSI, 2007). This available data can be used in countering suicide terrorism by tracking down members of society with these features. Most of the suicide terrorist ranks are swelled by the youths because of their gullible nature to notions of heroism, glory and a false sense of importance. This emanates from their idleness and vulnerability caused by widespread unemployment, religious extremism and social turmoil which expose them to violent and extreme organizations. This in turn fuels their untapped energy and zeal and hence makes them feel that they are part of a larger system than themselves. However, it is rare to find married individuals volunteering to be suicide bombers because of their family obligations. Given this observation, it is crucial to socialize the vulnerable youths as part of something bigger than themselves (such as: sports teams, community service group and non-extreme religious organizations) and this will influence them to abstain from terrorism. This will make it difficult for suicide terrorist organizations to lure the youth into their organizations since they would feel that they have something to live for.

The Arab world views shame as a painful and undignified form of existence thus prefer to die with dignity than to live in shame. These feelings of shame and indignity inherent in the Arab culture are harnessed by terrorist organizations which use them to indoctrinate and influence the young to carry out suicide operations (RUSI, 2007). In light of this, it is important to launch de-radicalization programs. This shame emanates from a deep sense of military occupation and victimization by an enemy who is perceived as 
immoral and militarily invincible inciting a sense of desperation such that no method used in driving the perceived enemy out is taboo, including suicide attacks. For this reason, measures to restore the lost dignity and pride can go a long way in reducing and even creating new ties with the hostile communities. This is because many communities in the Middle East have been destroyed by the United States and allies' war on terror campaigns since the beginning of the millennium and have left communities in shambles and seething with the desire for revenge. Therefore, it is imperative to promote dialogue, especially with the destroyed communities, by apologizing for the damage done and providing basic necessities such as shelter, water supply, food, clothing and medical treatment in these communities since the terrorist organizations use these very same grievances to swell their membership with recruits and potential suicide operatives and also acquire safe havens (Quintana, 2015).

The fact that most radical Islamic organizations are grounded on strict moral codes and values, such that tendencies like prostitution, adultery, homosexuality, abortion and religious tolerance among others are punishable by the most extreme measures, including death, is a possible weakness that can be used against them. Thus, rather than killing the leaders of these groups, which is usually counter-productive, there is also the need to broadcast their secret activities, especially those actions that contradict the moral codes of their organizations, such as sexual perversions, embezzlement of funds or any other dirty secret whether they did it in the past. This will force both the communities and followers to lose faith in their leaders and can also help in weakening these organizations since they take pride in their ability to adhere to a strict code of conduct and leaders with a compromised character will lose their ability to indoctrinate and direct their followers since they are not fit to lead a "holy war" when they are found to be "unholy". More so, these above suggested forms of counter-terrorism which support a non-violent and communication based approach to countering suicide terrorism are also very cheap in terms of human life, time, logistics and financial resources, as they can be used by individual communities and states attempting to curb the spread of suicide terrorism.

We conclude by stating that attacking the ability to indoctrinate by terrorist organizations via open-ended containment is a mammoth task but it can yield long lasting results as compared to other counter-terrorism measures that are currently in use, such as military operations, preventing terror financing, targeting leaders, compromising to some of the terrorist demands or isolating targets, among others. These counter terror strategies, if successful, are usually short-lived and have a tendency of aggravating future suicide terror as the current situation is demonstrating. In addition, indoctrination is mainly responsible for the training, recruiting, expansion and creation of future terrorists and organizations. Consequently, targeting the ability to indoctrinate will result in removing an organization's ability to expand, recruit and train new members, meaning that terrorism and the organizations responsible will die a natural death. 


\section{References}

1. Araj, B. (2008). Harsh State Repression as a Cause of Suicide Bombing: The Case of the Palestinian-Israeli Conflict. Studies in Conflict \& Terrorism, 31, 284-303.

2. Araj, B., \& Brym, R. J. (2010). Opportunity, Culture and Agency: Influences on Fatah and Hamas Strategic Action during the Second Intifada. International Sociology, 25(6), 842-868.

3. Atran, S. (2003). Genesis of Suicide terrorism. American Association for the Advancement of Science, 299, 1534-1539.

4. Azani E., Lvovsky, L. A., \& Haberfeld, D. (2016). Trends in Aviation Terrorism. International Institute for Counter-Terrorism. Herzliya: IDC.

5. Barton, G. (2016, March 2). Out of the ashes of Afghanistan and Iraq: the rise and rise of Islamic State. The Conversation. Retrieved from https://theconversation.com/out-ofthe-ashes-of-afghanistan-and-iraq-the-rise-and-rise-of-islamic-state-55437.

6. Bloom, M. (2005). Dying to Kill: Devising a Theory of Suicide Terror. Paper for Presentation to the Harrington Workshop on Terrorism. Austin: University of Texas at Austin, 113-150.

7. Bronk, J. (2015). The Air Campaign. In E. Quintana and J. Eyal (Eds.), Inherently Unresolved: The Military Operation against ISIS (pp.11-16). London: Royal United Services Institute.

8. Bronskill, J. (2015, June 23). RCMP say 1985 Air India bombing investigation 'active and ongoing. The Globe and Mail. Retrieved from www.theglobeandmail.com/news/ national/rcmp-says-1985-air-india-bombing-investigation-active-and-ongoing/arti cle25071447/.

9. Brown, L. (2016, September 29). CIA Director: Terrorist Groups 'Are Driven by This Ideology That Is Not Rooted in Islam. CNS News. Retrieved from www.cnsnews.com/ news/article/lauretta-brown/cia-director-terrorist-groups-are-driven-ideology-notrooted-islam.

10. Brym, R. J. (2007). Six lessons of suicide bombers. Contexts, 6(4), 40-45.

11. Brym, R. J. (2008). Religion, Politics, and Suicide Bombing: An Interpretive Essay. Canadian Journal of Sociology, 33(1), 89-108.

12. Brym, R. J. (2012). Collective and State Violence in the Palestinian-Israeli Conflict: The Limits of Classical Rational-Choice Theory. Canadian Review of Sociology, 49(3), 233-246.

13. Brym, R. J., \& Araj, B. (2008). Palestinian suicide bombing Revisited: A critique of the outbidding Thesis. Political Science Quarterly, 123(3), 485-500.

14. Brym, R. J., \& Araj, B. (2012). Are Suicide Bombers Suicidal?. Studies in Conflict \& Terrorism, 35(6), 432-443.

15. Brym, R. J., \& C. Hamlin. (2009). Suicide Bombers: Beyond Cultural Dopes and Rational Fools. In M. Cherkaoui, P. Hamilton and R. Boudon (Eds.), A Life in Sociology, vol. 2 (pp. 83-96). Oxford: Bardwell Press.

16. Bunker, R. J., \& Sullivan, J. P. (2004). Suicide Bombings in Operation Iraqi Freedom, No. 46. Arlington: The Institute of Land Warfare. 
17. Cordesman A. H. (2016). The Uncertain Trends and Metrics of Terrorism in 2016. Washington: Centre for Strategic and International Studies.

18. Cronin, A. K. (2002). Rethinking Sovereignty American Strategy in the Age of Terrorism. Survival, 44(2), 119-139.

19. Cusack, C. (2016, February 22). Did the Crusades lead to Islamic State? The Conversation. Retrieved from https://theconversation.com/did-the-crusades-lead-to-islamicstate-54478.

20. Daftary, F. (2016, February 21). Islamic State and the Assassins: reviving fanciful tales of the medieval Orient. The Conversation. Retrieved from https://theconversation.com/ islamic-state-and-the-assassins-reviving-fanciful-tales-of-the-medieval-orient-53873.

21. Davis, P. K., \& Jenkins, B. M. (2002). Deterrence and Influence in Counter terrorism: A Component in the War on al Qaeda. Pittsburgh: RAND National Defense Research Institute.

22. Doward, J. (2015, August $1^{\text {st }}$ ). Media coverage of terrorism 'leads to further violence'. The Guardian. Retrieved from www.theguardian.com/media/2015/aug/01/mediacoverage-terrorism-further-violence.

23. Duchesneau, J. (2015). Aviation Terrorism: Thwarting High-Impact Low-Probability Attacks. A PhD Thesis Submitted to the Division of Graduate Studies of the Royal Military College of Canada, Ontario.

24. Ellis, R., Fantz, A., Karimi, F., \& McLaughlin, E. C. (2016). Orlando shooting: 49 killed, shooter pledged ISIS allegiance. CNN. Retrieved from http://edition.cnn.com/2016/ 06/12/us/orlando-nightclub-shooting/.

25. Gabriel, W. (2014). New Terrorism and New Media. Washington: Commons Lab of the Woodrow Wilson International Center for Scholars.

26. Ganor, B. (2007, March 21). The Rationality of the Islamic Radical Suicide attack phenomenon. International Institute for Counter-Terrorism. Retrieved from www.ict.org.il/ Article/973/TheRationalityoftheIslamicRadicalSuicideattackphenomenon.

27. Global Terrorism Index. (2014). Measuring and understanding the Impact of Terrorism. New York: Institute for Economics and Peace.

28. Greenspan, J. (2013, December 20). Remembering the 1988 Lockerbie Bombing. History. Retrieved from www.history.com/news/remembering-the-1988-lockerbie-bombing.

29. Grimland, M., Apter, A., \& Kerkhof, A. (2006). The Phenomenon of Suicide Bombing. A Review of Psychological and Non-psychological Factors. Journal of Crisis Intervention and Suicide Prevention, 27(3), 107-118.

30. Hove, M., \& Ndawana, E. (2017). National instability as a threat to Africa's vision to transform borders from barriers into bridges of development. Migration and Development, 1-21.

31. Hughes, A. W. (2016, February 18). If Islamic State is based on religion, why is it so violent? The Conversation. Retrieved from https://theconversation.com/why-is-islamso-different-in-different-countries-51804.

32. Iddon, P. (2016, June 12). ISIS is losing battles, but has yet to lose the war. RUDAW. Retrieved from http://rudaw.net/english/analysis/12062016. 
33. Iqbal, K. (2010). Evolution of Suicide Terrorism in Pakistan and Counter-Strategies. Islamabad: Institute for Peace Studies.

34. Issacharoff, A. (2016, January 8). 450 of 452 suicide attacks in 2015 were by Muslim extremists, study shows. The Times of Israel. Retrieved from www.timesofisrael. com/450-of-452-suicide-attacks-in-2015-were-by-muslim-extremists-study-shows/.

35. Kaarbo, J., \& Ray, J. L. (2011). Global Politics: International Edition. Boston: Wadsworth.

36. Kaplan, E. H., Mintz, A., \& Mishal, S. (2006). Tactical Prevention of Suicide Bombings in Israel. Interfaces, 36(6), 553-561.

37. Kimhi, S., \& Even, S. (2004). Who Are the Palestinian Suicide Bombers?. Terrorism and Political Violence, 16(4), 815-840.

38. Lankford, A. (2011). Requirements and Facilitators for Suicide Terrorism: an Explanatory Framework for Prediction and Prevention. Perspectives On Terrorism, 5(5-6), 70-80.

39. Lawson, E. (2015). The Battle of the Narrative. In E. Quintana and J. Eyal (Eds.), Inherently Unresolved: The Military Operation against ISIS, (pp. 29-34). London: Royal United Services Institute.

40. Legault, A. (1992). The End of a Military Century?. Ottawa: International Development Research Centre.

41. Levinson, D., \& Christensen, K. (1996). The Global Village Companion. Santa Barbara, CA: ABC-CLIO.

42. Lynch, M. (2010). Rhetoric and Reality Countering Terrorism in the Age of Obama. Washington: Centre for New American Security.

43. Marone, F. (2013). Self-Sacrifice and Martyrdom in Terrorism: Political and Religious Motives. In R. W. Hefner, J. Hutchinson, S. Mels and C. Timmerman (Eds.), Religions in Movement: The Local and the Global in Contemporary Faith Traditions (pp. 132-146). London-New York: Routledge.

44. Marone, F. (2016). Italian Jihadists in Syria and Iraq. Journal of Terrorism Violence, 7(1), 20-35.

45. Marshal, A. G. (2010, October 4). Yemen: The Covert Apparatus of the American Empire. Global Research. Retrieved from www.globalresearch.ca/yemen-the-covert-apparatusof-the-american-empire/21306.

46. Martin, S., \& Weinberg, L. B. (2016). Terrorism in an Era of Unconventional Warfare. Terrorism and Political Violence, 28(2), 236-253.

47. Merriam-Webster. (2016). Definition of Indoctrinate. Merriam-Webster. Retrieved from www.merriam-webster.com/dictionary/indoctrinate.

48. Moghadam, A. (2005, May 12-13). The roots of suicide terrorism: A multi-causal approach. Conference paper presented for the Harrington Workshop on the Root Causes of Suicide Terrorism. Austin: University of Texas at Austin.

49. Moghadam, A. (2008). Motives for Martyrdom: Al-Qaida, Salafi Jihad, and the Spread of Suicide Attacks. International Security, 33(3), 46-78.

50. Moghadam, A. (2010). An Al-Qaeda Balance Sheet. Military and Strategic Affairs, 2(2), 95-100. 
51. Ni Aoláin, F. (2016). The 'war on terror' and extremism: assessing the relevance of the Women, Peace and Security agenda. International Affairs, 92(2), 275-291.

52. Quintana, E. (2015). Countering ISIS - A Military Operation to Buy Time. In E. Quintana and J. Eyal (Eds.), Inherently Unresolved: The Military Operation against. ISIS, (pp. 1-10). London: Royal United Services Institute.

53. Reynolds P. (2003). UTA 772: The forgotten flight. Retrieved from http://news.bbc.co. uk/2/hi/uk_news/3163621.stm

54. Rudd, S. (2016). The Chronology of Judges solved!. The Interactive Bible. Retrieved from www.bible.ca/archeology/bible-archeology-exodus-route-date-chronology-of-judges. htm.

55. RUSI Monitor. (2007, November 13). Countering suicide bombing - Part I. RUSI Monitor. Retrieved from https://rusi.org/publication/countering-suicide-bombing-part-i.

56. Salter, F. (2008). Ethnicity and Indoctrination for Violence: The Efficiency of Producing Terrorists. In I. Karawan, W. McCormack and S. Rreynolds (Eds.), Values and Violence: Intangible Aspects of Terrorism (pp. 63-79). New York: Oxford University Press.

57. Schmid, A. P. (2015). Challenging the Narrative of the Islamic State. Hague: International Centre for Counter-Terrorism.

58. Searcey, D. (2016). How Boko Haram Trains Abducted Women and Girls to Be Suicide Bombers. Richard Dawkins Foundation. Retrieved fromhttps://richarddawkins. net/2016/04/how-boko-haram-trains-abducted-women-and-girls-to-be-suicidebombers/.

59. Sela-Shayovitz, R. (2007). Suicide Bombers in Israel: Their Motivations, Characteristics, and Prior Activity in Terrorist Organizations. International Journal of Conflict and Violence, 1(2), 160-168.

60. Tomkiw, L. (2016, June 29). List of Recent ISIS Attacks: Islamic State Group Hits Targets From Belgium To Syria In 2016. International Business Times. Retrieved from www.ib times.com/list-recent-isis-attacks-islamic-state-group-hits-targets-belgium-syria2016-2388059.

61. Troy, M. (2006). Transatlantic Cooperation in the War Against Terror Financing: Building a Counter-Network. Jean Monnet/Robert Schuman Paper Series Vol. 6 No. 6. Miami: Miami European Union Center.

62. Walzer, M. (1977). Just and Unjust Wars. New York: Basic Books.

63. Wolfendale, J. (2007). Terrorism, Security, and the Threat of Counter-terrorism. Studies in Conflict \& Terrorism, 30, 75-92.

64. Wu, P. (2015). Impossible to Regulate: Social Media, Terrorists, and the Role for the UN. Chicago Journal of International Law, 16(1), 283-310. 